\title{
Prototipe Alat Pendeteksi Kelainan Kelenjar Tiroid Dengan Menggabungkan Teknik Iridologi Dan Elektrokardiografi Berbasis Jaringan Saraf Tiruan
}

\section{Prototype Tool Detection Thyroid Gland Disorders By Combining Technique Electrocardiographic And Iridology Based On Neural Network}

\author{
Rahmat $^{1)}$, Defni $^{2)}$, Firdaus $^{3)}$ \& Gustina Indriati ${ }^{4}$ \\ 1),3) Jurusan Teknik Elektro Politeknik Negeri Padang Kampus Unand Limau Manis Padang, \\ Telp. 0751-72590 Fax.0751-72576. Email : akhmed_01@yahoo.com \\ ${ }^{2)}$ Jurusan Teknologi Informasi Politeknik Negeri Padang Kampus Unand Limau Manis Padang, \\ Telp. 0751-72590 Fax. 0751-72576. Email : defni.devan@gmail.com \\ ${ }^{4)}$ Jurusan Biologi STKIP PGRI Sumbar
}

\section{ABSTRACT}

Some of the external symptoms of hyperthyroidism may be experienced by people who are not suffering from hyperthyroid disease, therefore needs a thorough examination and diagnosis for patients with hyperthyroidism that drug delivery and targeted therapy. A thorough examination of this costly and quite a long time. This research make a prototype instrumentation to help detect the presence of symptoms of thyroid gland disorders, especially hyperthyroidism, do not use chemicals and does not hurt the patient.

The principle of this tool is to combine technology with electrocardiographic Iridology specifically based artificial neural network. In the first year is the design and realization of a prototype of the channel electrocardiograph-based personal computer for measurement of cardiac patients megalami signal abnormalities tachycardia (one of the symptoms of hyperthyroidism). Electrocardiography will measure and display signal to monitor a patient's heart, can store data and make a decision whether the patients had tachycardia heart rhythm disorder or not. In both make iridology devices based neural network to detect any abnormalities of the thyroid gland through the iris image.

Electrocardiography device coupled with iridology software in order to get a prototype for the detection of hyperthyroidism through the measurement of two variables: cardiac signal and image of the iris. The Merger is software into a single entity has not done separately but have been able to perform measurements on patients. Tests have been conducted on 8 (eight) patients and has not been accompanied by a doctor, the conclusion of the test is that all patients tested did not experience hyperthyroidism.

Keywords: thyroid gland, hyperthyroidism, electrocardiography, iridology, artificial neural Network

\section{PENDAHULUAN}

Gejala luar dari penyakit kelainan kelenjar tiroid khusunya hipertiroid diantaranya adalah susah tidur, detak jantung lebih cepat dari kondisi normal, berkeringat, nafsu makan bertambah, sering buang air besar, rambut rontok, mata menjadi lebih besar (menonjol keluar) dan badan menjadi kurus dengan dratis. Beberapa gejala luar hipertiroid tersebut mungkin saja dialami oleh orang yang bukan mengidap penyakit hipertiroid oleh karena itu perlu pemeriksaan dan diagnosis menyeluruh bagi penderita hipertiroid agar pemberian obat dan terapi tepat sasaran. 
Saat ini beberapa alternatif pemeriksaan yang dilakukan adalah mengetahui dulu status horman tiroid dengan pemeriksaan FT4 dan TSH melalui darah, USG kelenjar tiroid dan scanning kelenjar tiroid. Pengobatan kelainan ini tergantung dari status hormon tiroid (hipertiroid, eutiroid atau hipotiroid), dari USG akan diketahui apakah mengandung cairan (kista tiroid) dan dari scanning tiroid (Hot atau cold) nodul.

Pendeteksian kelenjar tiroid lain adalah sebuah alat yang diberi nama Thyroid Uptake IT4. Diagnosisnya dengan cara pasien menelan kapsul berisi radioisotop yodium, radioisotop ini meluruh paling lama delapan hari, setelah meminum kapsul radioisotop yodium berselang 2 jam, 4 jam, 24 jam, dan 48 jam, dilakukan pendeteksian kelenjar tiroid. Kadar tangkapan radioisotop oleh kelenjar tiroid akan terdeteksi dan diwujudkan pada perangkat lunak komputer menjadi informasi grafis kurva tiroid.

Penelitian ini merencanakan instrumentasi yang dapat membantu mendeteksi adanya gejala kelainan kelenjar tiroid khususnya hipertiroid, tidak menggunakan bahan kimia dan tidak melukai pasien. Prinsip alat ini adalah menggabungkan teknologi iridologi dengan elektrokardiograf khusus berbasis jaringan saraf tiruan. Proses pendeteksian kelainan kelenjar hipertiroid diserahkan pada komputer. Sehingga proses pendeteksian dilakukan secara otomatis yang hasil dignosisnya tidak terpengaruh oleh waktu dan keadaan. Setelah pelaksanaan kegiatan ini, maka akan dikuasai dan diperoleh sebuah teknologi instrumentasi kesehatan yang menggabungkan dua teknologi sekaligus.

Penelitian tahun pertama adalah desain dan realisasi sebuah elektrokardiograf khusus berbasis komputer pribadi untuk pengukuran sinyal eleektrokardiogram (sinyal jantung) pasien yang megalami kelainan kelenjar tiroid khususnya hipertiroid. Elektrokardiograf ini akan mengukur dan menampilan sinyal elektrokardiograf pada monitor, dapat menyimpan data dan mengambil keputusan apakah jantung pasien mengalami takikardia atau tidak. Penelitian tahun kedua membuat instrumentasi iridologi khusus untuk menentukan apakah apakah pasien mengalami kelainan kelenjar tiroid atau tidak. Pada tahun kedua ini dilakukan pengujian terhadap pasien dengan menggabungkan hasil pengujian elektrokardiografi dan pengujian iridologi. Dari kedua hasil tersebut kemudian diambil kesimpulan, apakah pasien mengalami hipertiroid atau tidak.

\section{Kelenjar Tiroid}

Kelenjar tiroid lebih dikenal dengan kelenjar gondok, berguna untuk menghasilkan hormon yang penting fungsinya bagi metabolisme tubuh. Dalam tubuh, letak kelenjar ini di sebelah kanan dan kiri leher. Jika tubuh kurang Yodium, kelenjar ini akan membengkak. Gangguan tiroid paling parah disebabkan oleh ketidak seimbangan sistem kekebalan tubuh. Selsel yang berfungsi menghancurkan bibit penyakit yang masuk ke dalam tubuh justru berbalik menyerang kelenjar tiroid karena kelenjar itu tidak mampu lagi mengeluarkan hormon esensial bagi metabolisme tubuh.

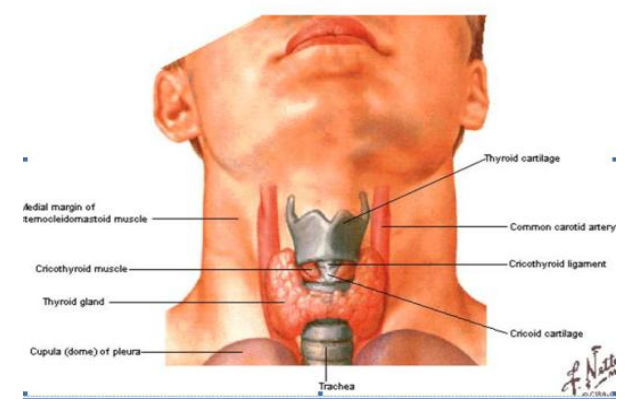

Gambar 1. Letak kelenjar tiroid dalam tubuh [8]

\section{Elektrokardiografi}

Elektrokardiografi adalah sebuah alat yang dapat menangkap sinyal listrik yang dihasilkan jantung saat melakukan 
tugasnya mengambil darah kotor dan memompa darah bersih keseluruh tubuh. Sinyal listrik tersebut dinamakan juga elektrokardiogram atau disingkat EKG. Penggunaan sinyal elektrokardiogram sudah sangat umum di dunia kedokteran yaitu sebagai alat bantu untuk mendiagnosis kelainan pada jantung. Pola elektrokardiogram kondisi jantung umumnya memiliki pola yang khusus, tetapi untuk membedakan apakah jantung dalam keadaan sehat atau terdapat suatu kelainan fungsional pada jantung diperlukan keahlian dan pengalaman melakukan identifikasi dari bentuk-bentuk elektrokardiogram yang sudah ada [7].

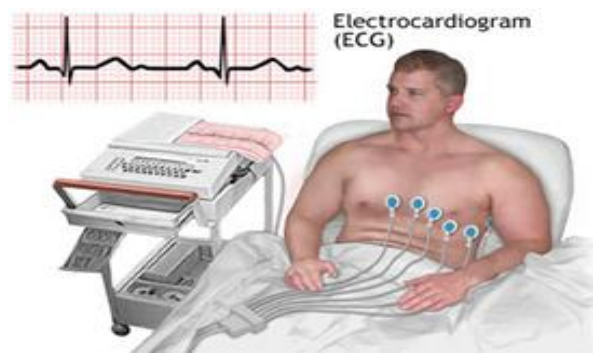

Gambar 2. Elektrokardiografi [8]

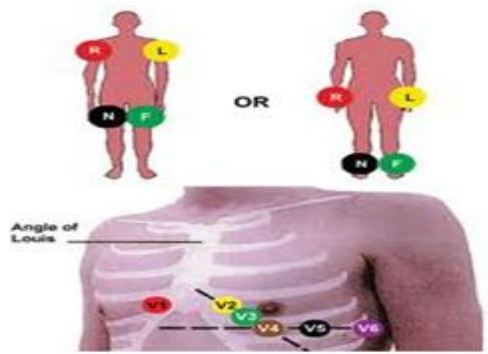

Gambar 3. Elektrokardiografi [8]

Kelainan yang terjadi pada sinyal elektrokardiogram dibedakan atas dua kelompok yaitu kelainan yang tidak mengikuti ritme yang benar dan kelinan pada bentuk defleksi komponen sinyal elektrokardiogram.

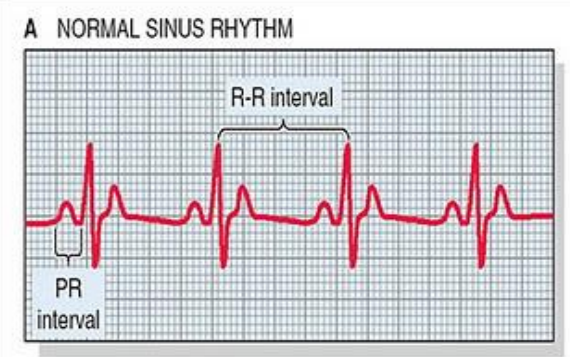

Gambar 4. Sinyal eleltrokardiogram normal [8]

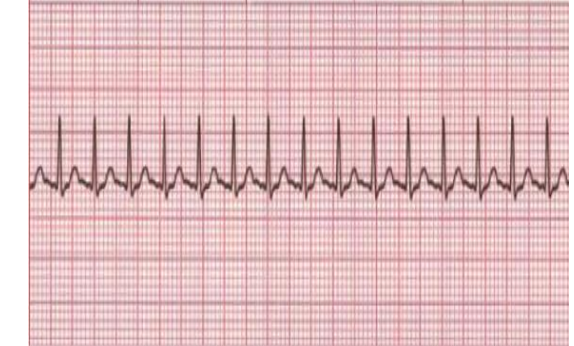

Gambar 5.Sinyal elektrokardiogram
takikardia [8]

Pada sinus takikardia, frekunensi jantungnya lebih dari 100 kali per menit. Peningkatan frekfensi jantung pada pasien dengan sinus takikardia biasanya terjadi oleh adanya respon fisiologi dari tubuh terhadap suatu keadaan yang menggangu hemostasis tubuh. Dari sekian banyak penyebab frekfensi jantung melebihi 100 $\mathrm{x} /$ menit pada kasus sinus takikardia, beberapa keadaan yang harus kita tahu diantaranya adalah gejala hipertiroid.

\section{Iridologi}

Iris mata adalah bagian hitam dari bola mata yang darinya dapat terlihat kondisi organ-organ tubuh yang lain pada diri manusia. Melalui iris dapat tergambar sistem tubuh, kekuatan dan kelemahannya, tahap kesehatan dan perubahan yang terjadi dalam tubuh. Ilmu yang mempelajari tentang cara mendeteksi (mengenali ) penyakit dan kondisi organ tubuh melalui iris mata tersebut dikenal dengan Iridologi. Iridologi relatif belum banyak diketahui orang, sebenarnya ilmu tersebut telah berkembang sejak berabadabad tahun yang lalu dan terus berkembang hingga kini. [2].

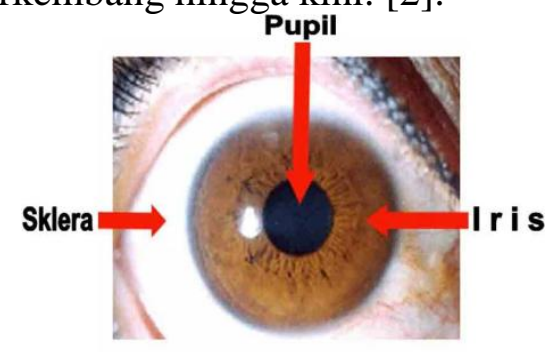

Gambar 6. Foto iris mata [3]

Dr. Bernard Jensen, PhD dari Alta Dena California USA yang telah 
melakukan pemotretan dan penelitian dengan kamera digital ciptaannya selama 18 tahun pada 150.000 pasiennya. Akhir tahun 1982 dia berhasil memperbaiki dan

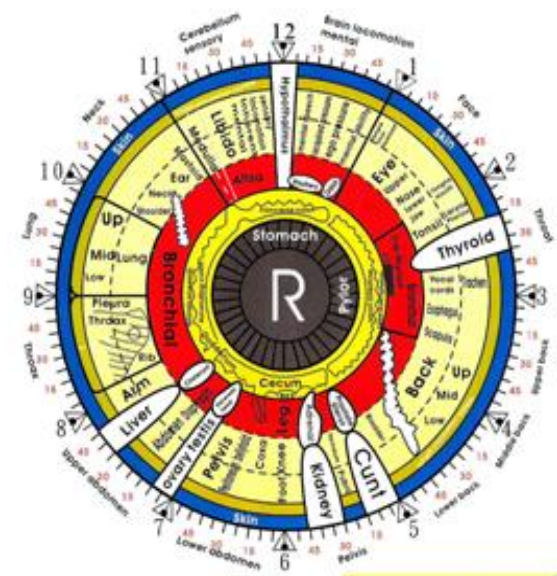

Gambar 7 Iridologi chart

\section{Jaringan Syaraf Tiruan}

Jaringan saraf tiruan atau dikenal juga dengan istilah neural network merupakan bagian dari Atificial Intelligence yaitu metode komputasi meniru prinsip kecerdasan manusia yang saat ini berkembang dan banyak digunakan untuk pemecahan masalah di berbagai bidang, termasuk pada bidang kesehatan dan kedokteran. [7]

\section{METODOLOGI}

Penelitian ini berlangsung selama dua tahun, tahun pertama adalah desain dan realisasi sebuah elektrokardiograf khusus berbasis komputer pribadi untuk pengukuran sinyal eleektrokardiogram (sinyal jantung) pasien yang megalami kelainan kelenjar tiroid khususnya hipertiroid. Pada tahun kedua membuat instrumentasi iridologi khusus untuk menentukan apakah apakah pasien mengalami kelainan kelenjar tiroid atau tidak. Pada tahun kedua ini dilakukan pengujian terhadap pasien dengan menggabungkan hasil pengujian elektrokardiografi dan pengujian iridologi. Dari kedua hasil tersebut kemudian diambil kesimpulan, apakah pasien mengalami hipertiroid atau tidak. menyempurnakan standar iridologi dan membuat Chart to Iridology yang dipakai luas di seluruh dunia sekarang ini. [2].

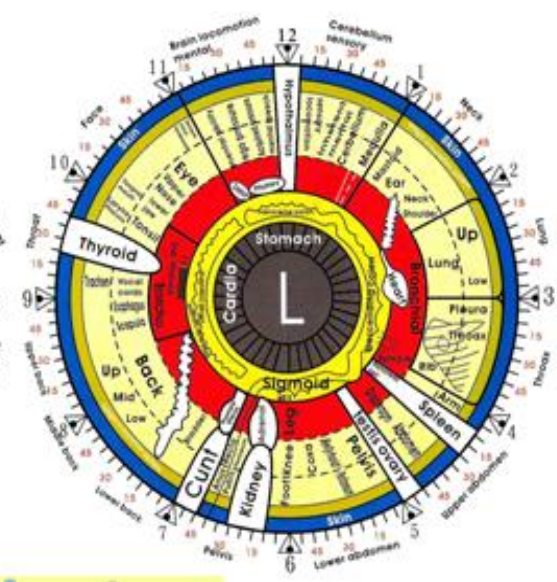

\section{Pembuatan Elektrokardiografi (EKG) Pada Tahun Pertama}

Ilustrasi dapat dilihat pada Gambar 9.

\section{Desaian Perangkat Keras [8]}

Desain perangkat keras merupakan desain rangkain elektronika yang membangun prototipe elektrokardiografi. Rangkaian elektronika tersebut terdiri atas tranduser, rangkaian penguat biopotensial dan rangkaian antar muka. Untuk mendapatkan sinyal elektrokardiogram yang berasal dari aktifitas jantung, digunakan elektroda biopotensial yang merupakan penghubung antara bagian tubuh dengan rangkaian penguat biopotensial. Pada penelitian ini digunakan elektroda permukaan tubuh yaitu disposile eletrode dan elektrode cardio clip. Penguat biopotensial merupakan penguat sinyal kecil yang akan memperkuat sinyal yang dihasilkan jantung ketika melakukan aktifitasnya. Penguat biopotensial terdiri atas penguat awal, high pass filter, low pass filter, notch filter, penguat non inverting dan penguat penjumlah.

\section{Desain Perangkat Lunak [8]}

Perangkat lunak merupakan program komputer untuk melengkapi perangkat keras agar dapat berfungsi. Terdiri atas 
program akuisisi data, filter, pengkondisi $\mathrm{R}$ to $\mathrm{R}$ dan pengambil keputusan.

Fungsi-fungsi yang digunakan dalam program untuk ATmega8 diantaranya adalah komunikasi serial, fungsi I/O port mikrokontroler, Timer/Counter0, dan ADC.

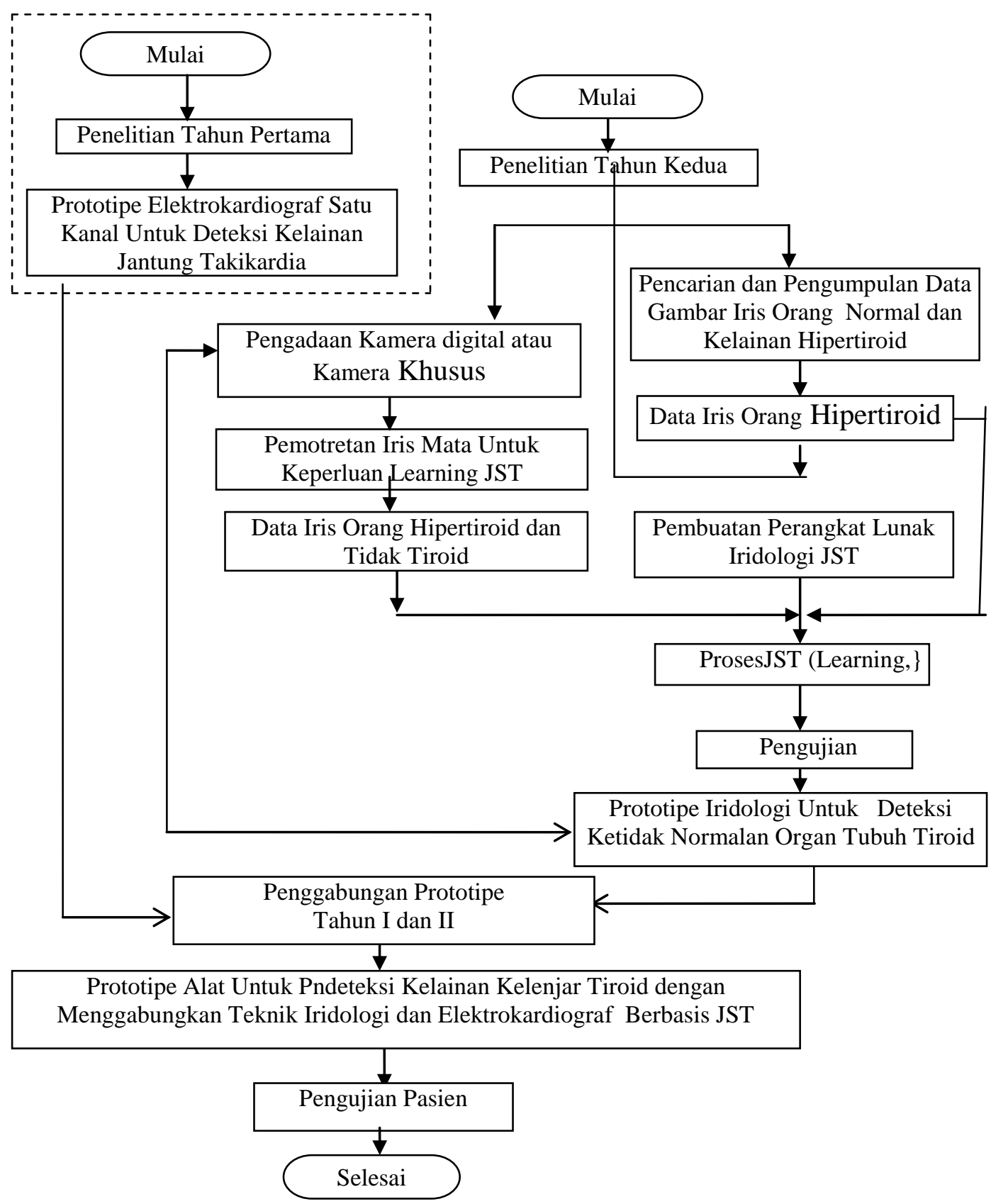

Gambar 8. Diagram alir penelitian

Mikrokontroler diprogram untuk merespon request dari komputer. Jika ada request dari komputer, program akan mengirim karakter dan meminta mikrokontroler untuk memulai proses konversi Pengiriman data dilakukan secara terus menerus sampai ada request dari komputer agar mikrokontroler berhenti melakukan proses konversi. Komunikasi data secara serial dilakukan untuk mengirimkan data hasil konversi tegangan analog ke digital, dan mengirim data serial ke PC dengan mengggunakan 
komunikasi serial RS232 dengan menggunakan kecepatan 9600 BPS.

Data sinyal elektrokardiogram diambil sebanyak 2000 data, dengan frekuensi sampling $200 \mathrm{~Hz}$. Untuk mengatur offset sinyal agar sesuai dengan keadaan yang sebenarnya, maka dilakukan proses pengurangan amplitudo sinyal dengan mengurangi dengan konstanta nilai 0.25 , pada persamaan $x[n]:=($ buffer*3/255)0.25. Dan setiap pengambilan data 2000 point, maka buffer dan layar series akan dibersihkan sehingga proses pengambilan data akan dimulai dari $\mathrm{T}=0$

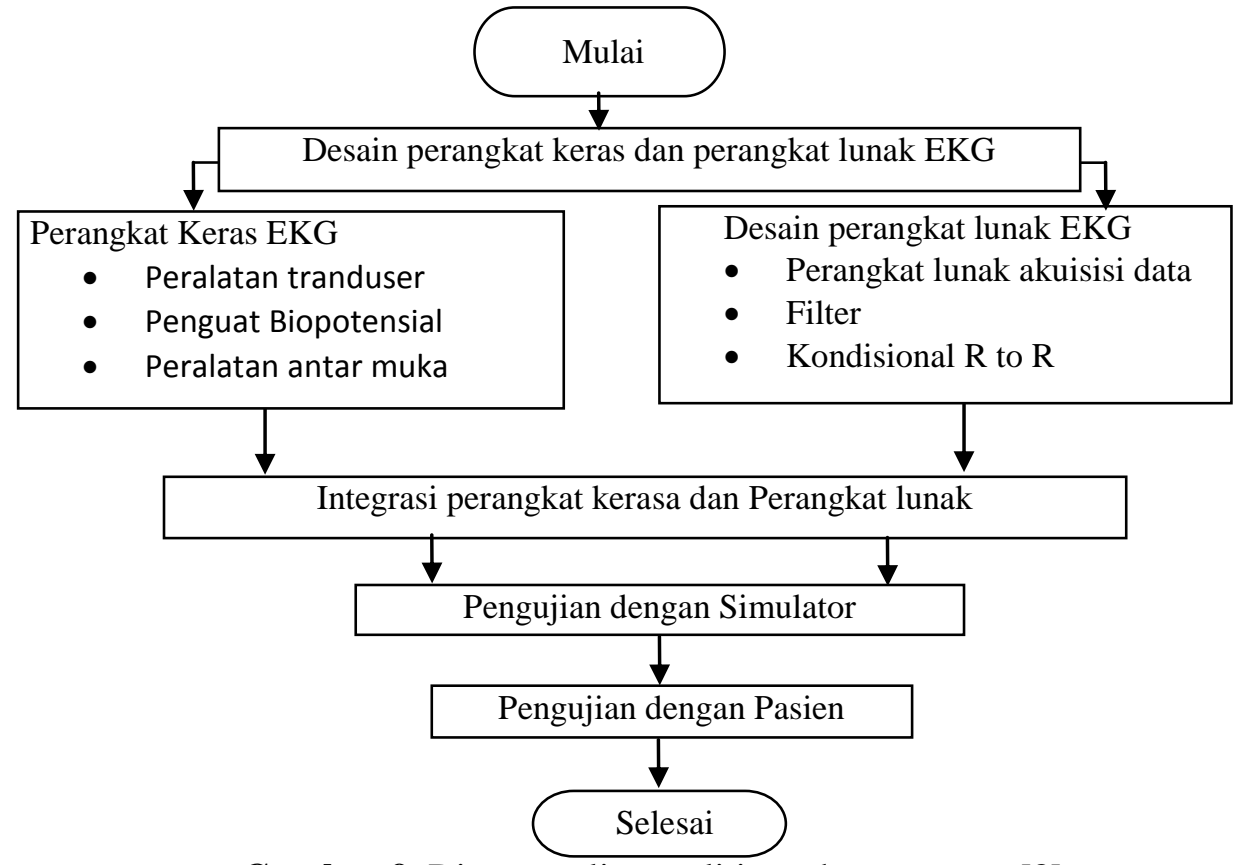

Gambar 9. Diagram alir penelitian tahun pertama [8]

Untuk menentukan jumlah detak jantung permenit (bpm) dari sinyal elektor kardiogram, maka perlu dilakukan proses deteksi jarak komponen $\mathrm{R}$ to $\mathrm{R}$, setelah didapatkan lebar $\mathrm{R}$ to $\mathrm{R}$, maka proses selanjutnya adalah konversi lebar $\mathrm{R}$ to $\mathrm{R}$ ke bpm. Proses thresholding dilakukan dengan mencari data terbesar dari 2000 data dan dari proses thresholding ditentukan nilai dengan nilai sebesar 0.75 dari nilai maksimal atau terbesar. Penentuan threshold ini dilakukan secara dinamik, yang bergantung terhadap data level sinyal yang masuk pada ADC.

Sebelum menentukan nilai BPM maka terlebih dahulu dilakukan proses penentuan panjang $\mathrm{R}$ to $\mathrm{R}$, yang dihitung sebanyak 3 buah komponen sinyal $\mathrm{R}$ to $\mathrm{R}$, dengan persamaan $\mathrm{R}:=(((\mathrm{R} 2-\mathrm{R} 1)+(\mathrm{R} 3-$ $\mathrm{R} 2)+(\mathrm{R} 4-\mathrm{R} 3)) / 3)^{*} 0.005 * 0.5 ; / / \mathrm{fs}=200 \mathrm{~Hz}$; Persamaan tersebut digunakan untuk merata-rata nilai $\mathrm{R}$ to $\mathrm{R}$, untuk konversi ke satuan waktu, disesuaikan dengan frekuensi sampling yang digunakan untuk proses pengambilan data $\mathrm{t}$ sampling= $1 / 200$, atau 0.005 s. Nilai 0.5 digunakan sebagai konstanta kalibrasi, yang dipilih agara nilai bpm yang ditampilkan sesuai dengan kalibrator. Proses konversi nilai $\mathrm{R}$ to $\mathrm{R}$ dilakukan dengan menggunakan persamaan $b p m=60 / R$. Proses diagnosis dilakukan dengan mengukur nilai bpm sinyal, sesuai dengan refernsi bahwa apabila bpm diatas 100 berarti hasilnya adalah takikardia selain tersebut, adalah tidak takikardia

\section{Pembuatan Perangkat Iridologi (Penelitian Tahun Kedua)}

Penelitian pada tahun kedua pada dasarnya adalah membuat perangkat lunak untuk identifikasi kelainan kelenjar tiroid. Citra iris mata diambil dari dua sumber yaitu secara langsung atau secara tidak langsung Citra iris secara langsung diakuisisi langsung menggunakan kamera 
digital sedangkan citra irs yang tidak ada dalam bentuk file image. langsung merupakan citra iris yang sudah
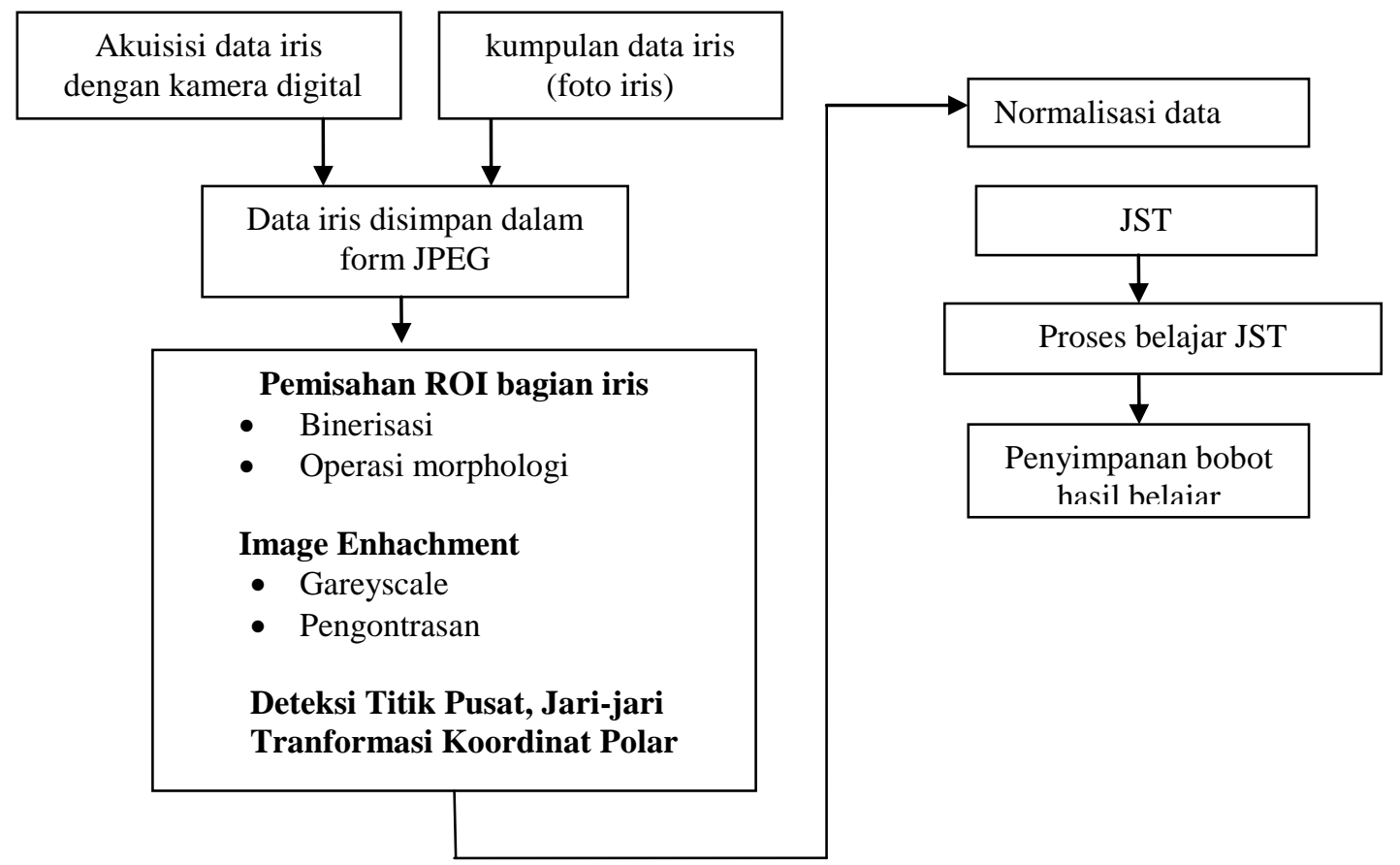

Gambar 10. Diagaram alir desain perangkat lunak instrumentasi iridologi

Secara umum perangkat lunak yang dikembangkan ini terdiri atas 5 (lima bagian) yaitu Image Processing (pemroesan citra), Extracion Feature (ektrasi ciri), Training (pembelajara), Medical Record (merekam data pasien), Pemeriksaan dan Reporting Data.

\section{Pemrosesan Awal Citra}

Citra iris yang telah dipilih dan yang akan dimuat ke dalam perangkat lunak, akan selalu diubah menjadi citra iris abuabu 8-bit. Proses pengubahan ini tidak memakan waktu lama, tetapi tegantung pada resolusi citra iris yang dikonversi. Sebagai contoh citra iris $352 \times 288 \times 24$ akan sangat cepat diubah menjadi abu-abu, sedangkan citra iris $1024 \times 768 \times 24$ memakan waktu yang sedikit lebih lama.

Pemisahan citra iris dari citra mata dan citra pupil dilakukan secara semi otomatis, dimana penguji harus memilih bagianbagian tertentu dari citra pupil dan citra iris, masing-masing membuat titik sebanyak 3x, untuk membentuk lingkaran yang melingkupi pupil dan iris.
Selanjutnya bagian dalam lingkaran kecil dan bagian luar lingkaran besar akan dihapus, dengan demikian hanya bagian iris saja yang tersisa.

Citra mata yang diambil menggunakan kamera, selalu tidak sama antara satu pengambilan dengan waktu pengambilan yang berikutnya. Hal ini bisa terjadi karena misalnya jarak dari kamera ke mata, pencahayaan, kemiringan kepala pasien yang diambil citra mata, dan lain-lain. Oleh karena itu menjadikan citra iris menjadi tidak lagi berbentuk lingkaran dengan diameter $\mathrm{R}$, tapi diubah menjadi citra persegipanjang dimana panjangnya adalah sudut 0-360 derajat, dan lebarnya adalah Dalam pemrosesan citra iris ukuran dan bentuk seharusnya tidak mempengaruhi perhitungan. Oleh karena itu citra iris harus dinormalisasi hingga ukuran tidak lagi berpengaruh terhadap perhitungan. Normalisasi iris dilakukan jari-jari iris dikurangi dengan jari-jari pupil. Dengan demikian bagaimanapun suatu citra iris diperoleh, maka ukurannya selalu tetap yaitu panjang 360 dan lebar 
$\mathrm{R}_{\text {iris }}-\mathrm{R}_{\text {pupil. }}$ Persamaan yang digunakan adalah: $\quad x_{i}(\theta)=x_{i 0}(\theta)+r_{i}^{*} \cos (\theta)$ dan $y_{i}(\theta)=y_{i 0}(\theta)+r_{i} * \sin (\theta)$. Dimana $\mathrm{x}_{\mathrm{i} 0}(\theta)$, $\mathrm{y}_{\mathrm{i} 0}(\theta)$ : titik pusat lingkaran $\theta$ : sudut.

Dalam perancangan ini citra polar dibentuk dari citra lingkaran dengan titik pusat adalah titik pusat iris. Dengan demikian setiap titik pada citra polar menunjukkan posisinya (jarak dan sudut) dari titik pusat iris tersebut. Untuk bagian dalam dari iris yang berdekatan atau bersinggungan dengan keliling lingkaran pupil, kadang terdapat bagian pupil yang ikut dikonversi. Hal ini terjadi karena titik pusat iris dan pupil tidak mesti sama. Pada perancangan titik pusat keduanya dianggap sama (konsentrik), untuk menyederhanakan perhitungan. Pengaruh pada program tidak ada karena bagian tersebut tidak termasuk dalam region of interest dalam organ yang dianalisa.

\section{Segmentasi ROI (Region of Interest)}

Untuk melihat fungsi-fungsi dari organ yang akan dianalisa, maka perlu segmentasi bagian organ tersebut dalam citra iris (polar). Proses pengubahan ini berdasarkan chart iridologi yang telah dibuat oleh Dr. Bernard Jensen Ph.D Dimana letak masing-masing organ sudah tertentu, dan pada mata tertentu.

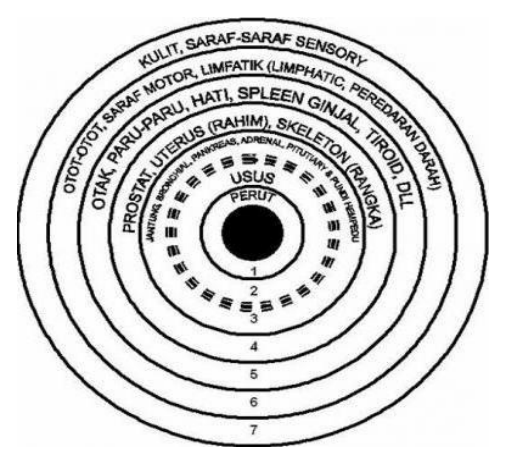

Gambar 11. Pembagian lokasi organ pada iris secara ring [2]

Karena citra polar sudah berupa sudut dan selisih jari-jari (hasil pengubahan citra iris cartesian ke citra iris polar), maka proses ini mudah. Organ yang akan diambil segmennya, dilihat posisinya pada chart iridology. Kemudian dilihat berapa posisi derajatnya, setelah itu dilihat berapa presentase lebarnya dari lebar iris, dan dimana mulai dan berakhirnya. Hasil segmentasi ROI adalah citra masingmasing organ persegi panjang dengan lebar selisih derajat, dan panjang selisih presentase lebar iris. Algoritma pemograman segmentasi ROI (Region of Interest) dengan Delphi dapat dilakukan sebagai berikut :

\section{Jaringan Saraf Tiruan (JST)}

Pada penelitian ini menggunakan metode propagasi balik dengan ukuran layer input dan hidden dipilih dengan jumlah tertentu hingga terbentuk struktur jaringan yang diharapkan pada proses untuk penentuan output. Ukuran besarnya layer input tergantung pada besarnya jumlah segmentasi citra. Ukuran banyaknya unit pada layer hidden dipilih maksimum lima unit, jumlah unit pada layer output terdiri dari dua unit.( Y1 dan Y2).

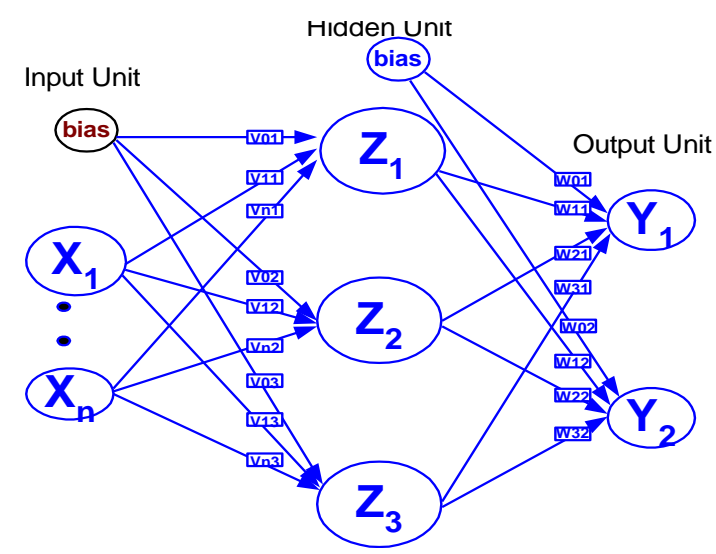

Gambar 12 . Arsitekturi jarinagn saraf tiruan yang digunakan

Prinsip perangkat lunak untuk jaringan diatas terdiri atas dua bagian yakni proses belajar dan proses pengujian. Pada proses pengujian serangkaian proses dari awal tetap dilakukan namun proses pembelajaran tidak dilakukan, hanya memcocokkan data dengan bobot yang telah disimpan pada proses pembelajaran. 


\section{HASIL DAN PEMBAHASAN}

Berdasarkan tahapan tahapan yang telah dilakukan pada tahun pertama dan tahun kedua telah dapat diimplementasikan sebuah prototipe alat pendeteksi kelainan kelenjar tiroid dengan menggabungkan teknik iridologi dan elektrokardiograf berbasis jaringan saraf riruan. Secara garis besar prototipe ini terdiri dari perangkat keras elektrokardiografi berupa perangkat elektronika elektrokardiografi berbasis komputer pribadi dengan aksesoris pendukung untuk pengukuran jantung dan perangkat iridologi yang terdiri perangkat lunak pengolahan citra iris dilengkapi dengan kamera digital dan kamera khusus iridology.

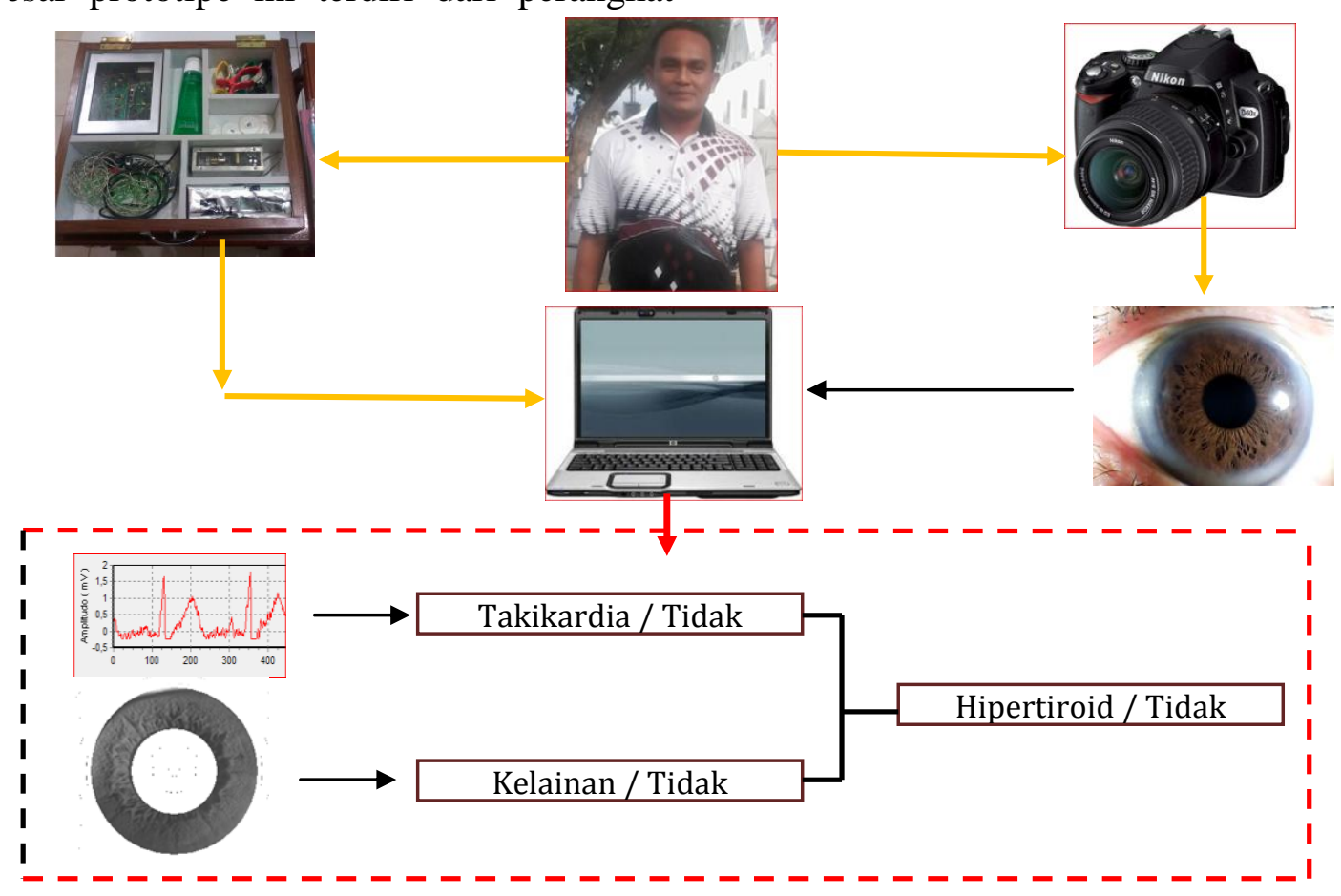

Gambar 13. Prototipe hasil penelitian dan ilustrasi deskripsi kerjanya

\section{Pengujian Prototipe Alat Pendeteksi Kelainan Kelenjar Tiroid dengan Pasien}

Pada pengujian ini dilakukan pengujian dua parameter sekaligus yaitu menguji kondisi sinyal jantung dan iris mata pasien. Pengujian baru dapat dilakukan terhadap pasien yang tidak mengalami hipertiroid dan belum didampingi oleh dokter. Hanya satu orang pasien yang mengalami hipertiroid berdasarkan pengakuan dan bukti hasil uji darah.
Cara pengujian adalah dilakukan pengukuran sinyal jantung dengan elektrokardiografi, pasien dalam keadaan istirahat. Keadaan detak jantung pasien (BPM) akan ditampilan pada komputer sekaligus keputusan apakah mengalami takikardia atau tidak. Hasil pengukuran ini dicatat dan dan dimasukan dalam tabel. Kemudian dilakukan pengambilan citra iris pasien dengan kamera digital dan kamera khusus iridologi, lalu dilakukan urutan proses pengolahan sesuai dengan yang telah dijelaskan pada metode diatas. 

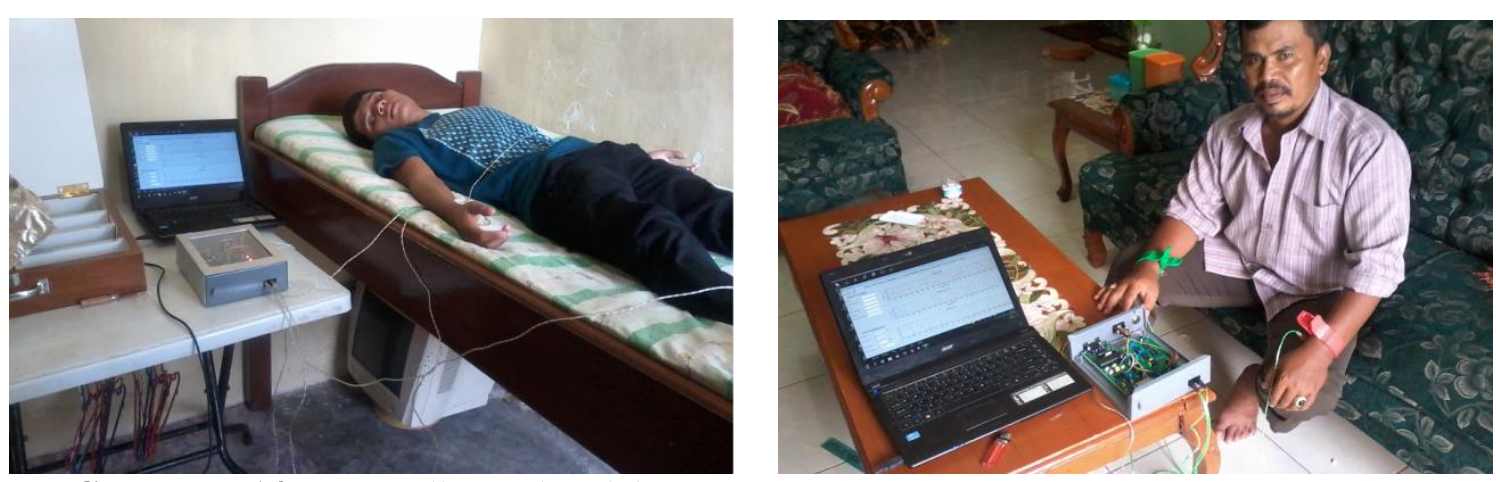

Gambar 14. Pengujian sinyal jantung pasien dengan elektrokardiografi
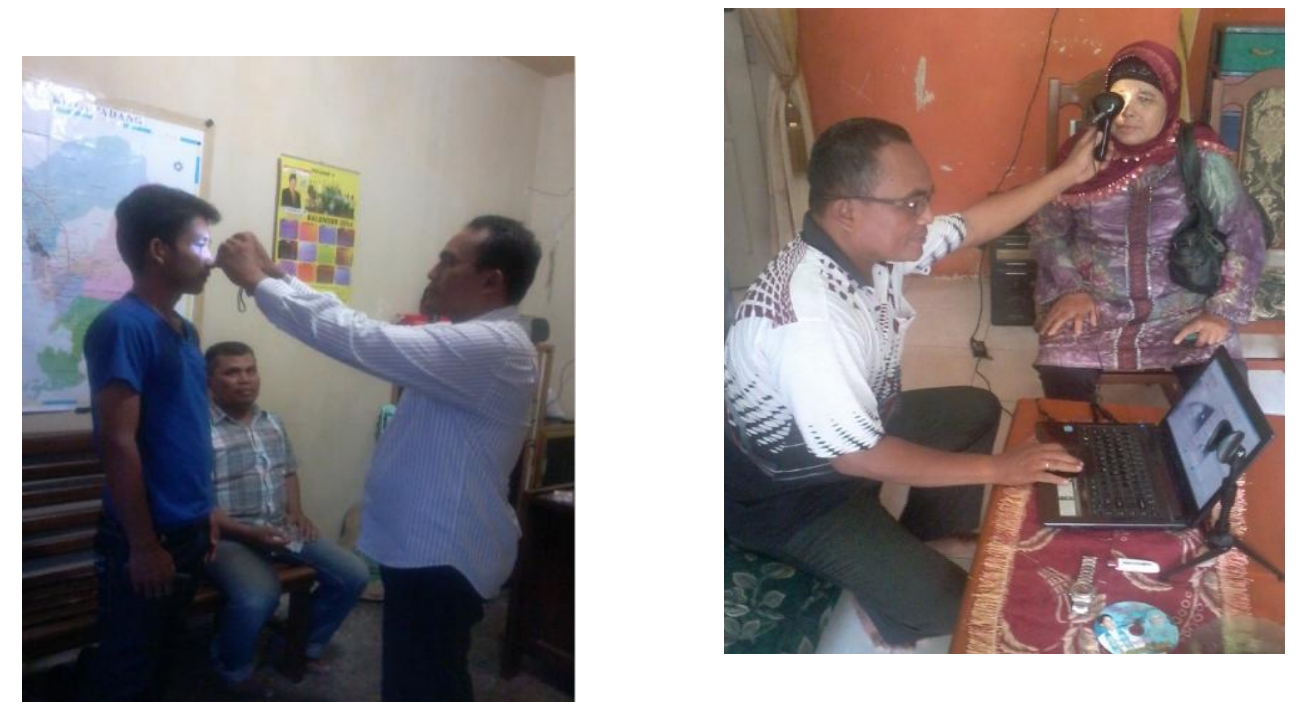

Gambar 15. Pengujian citra iris mata pasien dengan kamera digital dan kamera Khusus iridologi

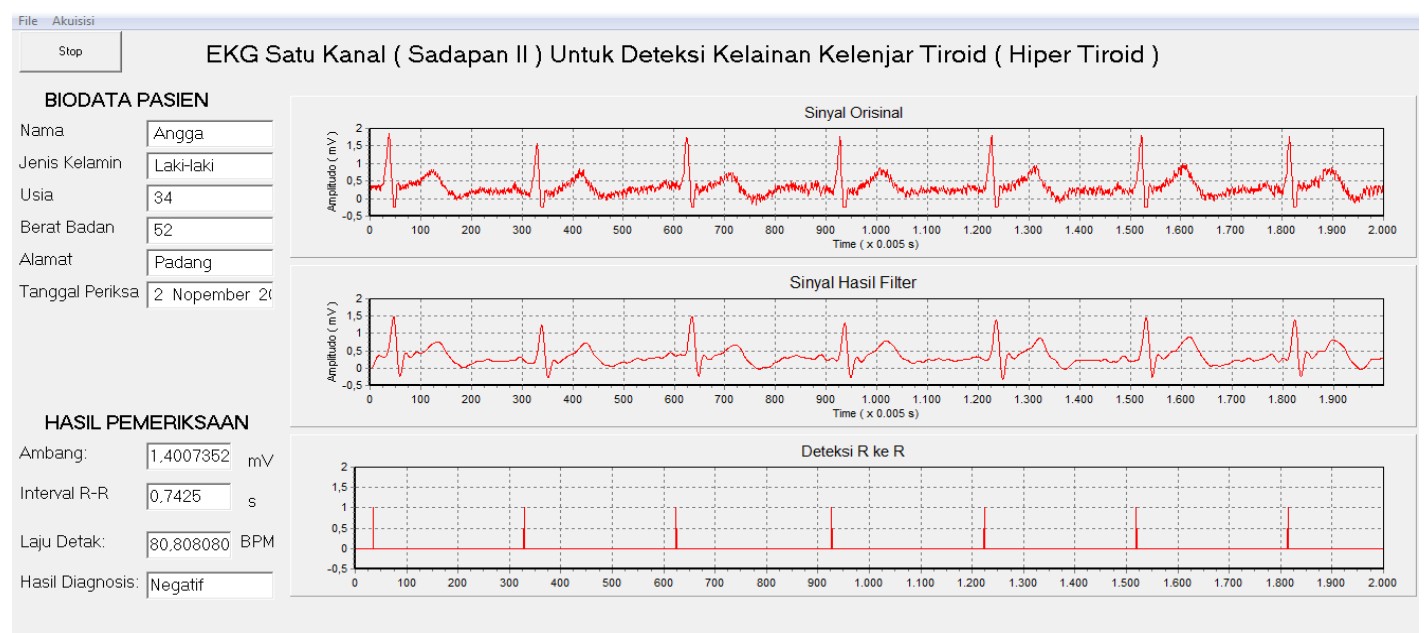

Gambar 16. Hasil pengujian sinyal jantung pasien dengan eilektrokardiografi 

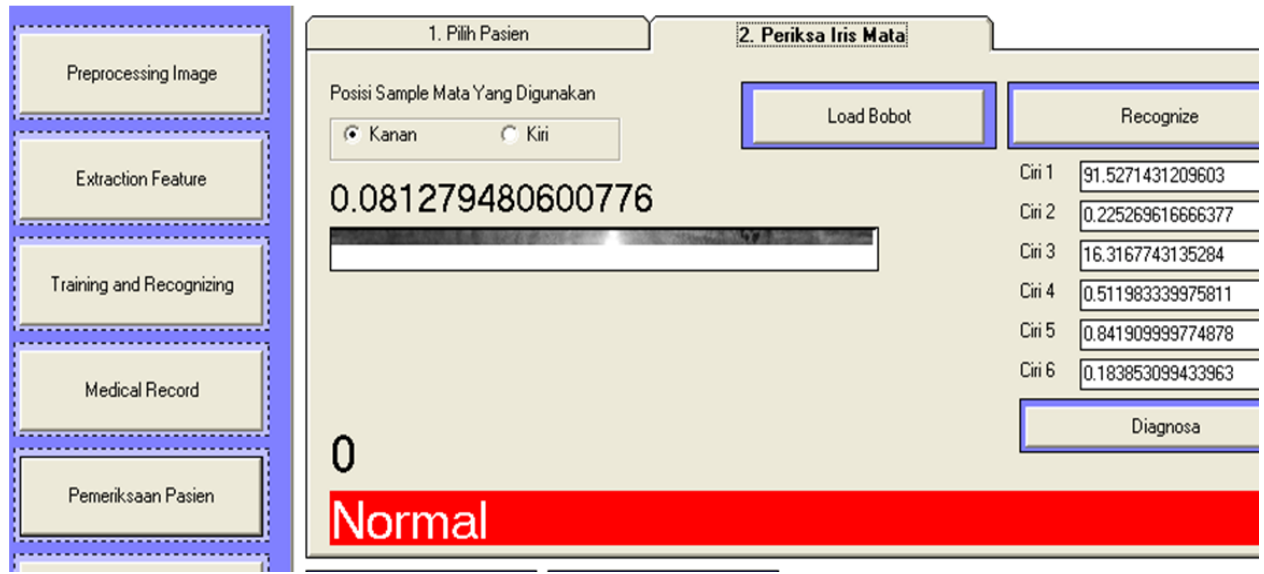

Gambar 17. Hasil pengujian iris mata pasien dengan iridologi

Tabel 1. Hasil pengujian terhadap 8 orang pasien

\begin{tabular}{|c|l|c|c|c|c|}
\hline No & Nama Pasien & Umur & $\begin{array}{c}\text { Elektrokardiograf } \\
\text { ( BPM) }\end{array}$ & $\begin{array}{c}\text { Iridologi } \\
\text { (Gejala Tiroid / } \\
\text { Tidak Gejala } \\
\text { Tiroid) }\end{array}$ & $\begin{array}{c}\text { Kesimpulan } \\
\text { Gejala } \\
\text { Hipertiroid / } \\
\text { Tidak }\end{array}$ \\
\hline 1 & Erli Yerlita & 65 & 86.2 & Tidak & Tidak \\
\hline 2 & Mukhtar Edi & 46 & 80,60 & Tidak & Tidak \\
\hline 3 & Vera & 37 & 74,56 & Tidak & Tidak \\
\hline 4 & $\begin{array}{l}\text { Zelfi } \\
\text { Rahmadiani }\end{array}$ & 40 & 89,73 & Tidak & Tidak \\
\hline 5 & Angga & 35 & 68 & Tidak & Tidak \\
\hline 6 & Elsa putri & 30 & 82,64 & Tidak & Tidak \\
\hline 7 & Edward & 43 & 76,15 & Tidak & Tidak \\
\hline 8 & Nar & 39 & 71,85 & Tidak & Tidak \\
\hline
\end{tabular}

\section{SIMPULAN}

1. Penelitian tahun pertama menghasilkan sebuah prototipe elektrokardiografi khusus untuk mengidentifikasi pasien apakah mengalalmi kelainan jantung takikardia atau tidak dan telah dilakukan perbandingan dengan elektrokardiograf standard rumah sakit

2. Penelitian tahun kedua dapat membuat perangkat iridologi berbasis jaringan saraf tiruan dan telah diuji dengan pasien yang bukan hipertiroid. Hasil pengujian perangkat iridologi ini dapat mengidentifikasi pasien tidak mengalami hipertiroid. Pengujian belum didampingi oleh dokter.
3. Secara keseluruhan Prototipe penelitian tahun pertama belum terintegrasi secara software dengan penelitian tahun kedua namun telah dapat digunakan untuk pengujian. Pengujian dilakukan terhadap 8 (delapan) oarang pasien, salah satu dari pasien tersebut sedang mengalami hipertiroid. Hasil pengujian menunujkan semuanya tidak mengalami hipertiroid. Pengujian ini juga belum didampingi oleh dokter

\section{DAFTAR PUSTAKA}

[1] Basyir, M. Pramadihanto, D. Purnomo, MH. 2005. Analisa Tekstur Iris Matadengan Metoda Gray Level Spatial 
Dependence Untuk Aplikasi Iridologi. Seminar Nasional Pasca Sarjana V. Surabaya

[2] D'Hiru.(2007). IRIDOLOGI. PT. Gramedia Pustaka Utama. Jakarta

[3] Fahmi (2007). Perancangan Algoritma Pengolahan Citra Mata Menjadi Citra Pola Iris Sebagai Bentuk Antara Sistem Biometrik. Karya Ilmiah. Departemen Teknik Elektro Universitas Sumatera Utara.

[4] Pramono, M. 2006. Aplikasi Metode Backpropagation Untuk Pengenalan Perubahan Abmormal Organ Pangkreas Melalui Iris Mata. Prosiding SNATI 2006. Universitas Islam Joyakarta. Hal D1-D3.
[5] Pratanu, S (2000). Kursus Elektrokardiografi. Bagian Kardiologi Fakultas Kedokteran Universitas Air Langga. Surabaya

[6] Syahrul. (2012). Mikrokontroler AVR Atmega8535. Informatika. Baundung.

[7] Rahmat, Rahmat S, Mauridhi HP (2006). Pengenalan Pola Sinyal EKG Menggunakan Jaringan Saraf Tiruan Levenberg Marquardt. Tesis Program Studi Magister ITS Surabaya.

[8] Rahmat, Defni, Yenita. 2014. The Design of One Channel Electrocardiography Prototype to Help One of Public Hyperthyroidism Symptoms. ASAIS. PNJ Jakarta 